\title{
Frederik DHONDT*
}

Free University of Brussels (VUB)/University of Antwerp/Ghent University

\section{'ARRESTEZ ET PILLEZ CONTRE TOUTE SORTE DE DROIT'**: TRADE AND THE WAR OF THE QUADRUPLE ALLIANCE (1718-1720)}

\begin{abstract}
The War of the Quadruple Alliance (1718-1720) was a conflict between Spain and the other major European powers over the balance of power in Italy. France and Britain jointly intervened on the side of the attacked party, Emperor Charles VI. In February 1720, the conflict was resolved when Philip V of Spain finally adhered to the Treaty of London (2 August 1718). The decision to go to war was contentious at the French court. For the benefit of public opinion, Philip, duke of Orléans and Regent of France, had to wage war against the Spanish Prime Minister, Cardinal Giulio Alberoni, rather than against the Sun King's grandson, Philip V. Moreover, whereas French and British diplomats found consensus as regards maintaining the principles of the Peace of Utrecht (11 April 1713), they remained commercial rivals. This article lifts a tip of the veil covering the complex trade relations during the conflict. Spain tried to placate and reassure French merchants, and conversely to punish their British counterparts. The British fleet patrolled the Mediterranean, searching French vessels as well as those of neutral states. The Emperor, though allied to France and Britain, could not prevent Neapolitan corsairs from preying on their trade. Moreover, French ships illegally furnished the Spanish army. Finally, France and Britain hoped to quell the abuse of neutral powers in the conflict (Tuscany, Genoa, Venice) by imposing upon them a duty to chase Spanish privateers from their harbours. The complaints of
\end{abstract}

* My thanks to the anonymous reviewers of this paper for their insightful comments, as well as to Dirk Heirbaut, Dave De Ruysscher, Jelten Baguet, Marco in ' $t$ Veld and the attendees of the St Andrews conference 'Balance of Power, Balance of Trade' on 21-22 January 2015 for their remarks and suggestions on an earlier version of this paper.

** Marginal note, Archives Nationales (AN), Marine, B1, fol. 299v. 
French traders, as indicated by the consuls to the Conseil de la Marine and the Regent himself at the apex of the French government, reveal pleas borne out of frustration, as well as appeals to either the law of nations or consular protection to shield merchants from assaults and abuses. When war was declared, inimical, friendly or allied relations in high politics seemed almost irrelevant. The military conflict generated uncertainty and damaged the reputation of the French flag. Diplomatic pressure on the neutral powers was seen as being more effective than reliance on seemingly corrupt or biased local jurisdictions. The Regent's management of the conflict - in close collaboration with Britain, despite all the difficulties on the ground - is all the more remarkable.

Keywords: Law of nations, legal history, commerce, War of the Quadruple Alliance, Regency, Italy

The Peace Treaties of Utrecht (11 April 1713), Rastatt (6 March 1714) and Baden (7 September 1714) were collectively a milestone in European diplomatic history. ${ }^{1}$ Conflicts which engulfed the whole of Europe were conspicuous by their absence until the Wars of the Polish Succession $(1733-1735)^{2}$ and the Austrian Succession (1740-1748). ${ }^{3}$ The Peace of Utrecht ended almost a century of gruelling conflict in Europe, from the Thirty Years' War to the War of the Spanish Succession. ${ }^{4}$ The partition of the composite Spanish monarchy between Habsburg and Bourbon

${ }^{1}$ Utrecht-Rastatt - Baden 1712-1714: Ein europäisches Friedenswerk am Ende des Zeitalters Ludwigs XIV., ed. by Heinz Duchhardt and Martin Espenhorst (Göttingen: Vandenhoeck \& Ruprecht, 2013); Lucien Bély, Espions et Ambassadeurs au Temps de Louis XIV (Paris: Fayard, 1990); The Treaties of the War of the Spanish Succession: An Historical and Critical Dictionary, ed. by Marsha Frey and Linda Frey (Westport: Greenwood, 1995); Rolf Stücheli, Der Friede von Baden (Schweiz) 1714 (Freiburg: Universitätsverlag, 1997); Heinhard Steiger, 'Rechtliche Strukturen der europäischen Staatenordnung 1648-1792', Zeitschrift für ausländisches öffentliches Recht und Völkerrecht, 59 (1999), 609-49.

2 John L. Sutton, The King's Honor and the King's Cardinal: The War of the Polish Succession (Lexington: University Press of Kentucky, 1980); Pierre Massuet, Histoire de la guerre présente contenant tout ce qui sest passé de plus important en Italie, sur le Rhin, en Pologne \& dans la plupart des Cours de l'Europe (Amsterdam: François l'Honoré, 1735).

3 Reed Browning, The War of the Austrian Succession (New York: St Martin's Griffin, 1995).

4 André Corvisier, 'Présence de la Guerre au XVII' Siècle', in Guerre et Paix dans l'Europe du XVII Siècle, ed. by Lucien Bély, Jean Bérenger and André Corvisier, 2 vols (Paris: S.E.D.E.S., 1991), I, pp. 13-27. 
was at the heart of these agreements of 1713-1714. Yet, inevitably, economic and trade disputes followed as a corollary. ${ }^{5}$ The territorial balance of power in Europe, established in 1713, was predicated on a commercial balance of trade on a global scale. ${ }^{6}$ Subsequently, trade issues occupied a secondary place in the diplomatic management of the system. Incidents between British and French subjects overseas were not allowed to escalate into a rupture of political relations and were generally settled through normal diplomatic channels. Numerous reported incidents could have given rise to a conflict between Britain and France, but these were not allowed to poison the Franco-British rapport. ${ }^{7}$ In the years between 1716 and 1718 , peace negotiations amending the treaties of Utrecht had priority over commercial quarrels. ${ }^{8}$

5 Antonella Alimento, 'Commercial Treaties and the Harmonisation of National Interests: The Anglo-French Case (1667-1713)', in War, Trade and Neutrality: Europe and the Mediterranean in the Seventeenth and Eighteenth Centuries, ed. by Antonella Alimento (Milan: FrancoAngeli, 2011), pp. 107-28; Armin Reese, Europäische Hegemonie und France d'outre-mer: Koloniale Fragen in der französischen Aussenpolitik 1700-1763 (Stuttgart: Steiner, 1988). The Politics of Commercial Treaties in the Eighteenth Century. Balance of Power, Balance of trade, ed. by Antonella Alimento and Koen Stapelbroek (London: Palgrave, 2017).

${ }^{6}$ See: Josiah Child, Discourse of Trade, Wherein is Recommended Several weighty Points relating to Companies of Merchants, the Act of Navigation, Naturalization of Strangers, and our Woollen Manufactures, the Ballance of Trade And the Nature of Plantations, and their Consequences, in Relation to the Kingdom, are Seriously Discusses, $3^{\text {th }}$ edn (London: Sowle, 1718).

7 On harsh treatment suffered by French merchants in the Mediterranean at the hands of Vice-Admiral Cornwall, and complaints of the French fishing population of Boulogne and St Valéry sur Somme, see: Chammorel, London, 28 June 1717: AN, Marine, B1, 32, fols 447 $-447^{\mathrm{v}}$. Or, during the War of the Quadruple Alliance, Admiral Byng's search of a French vessel destined for Alexandria, described as 'the harshest and most unjust search operation ever', see: de la Leurie, Naples, 13 December 1718. Two other seizures, of the vessels of the French captains Roux and Audibert, described as 'tyrannical', were justified by the admiral by reference to an order of the Regent to seize all French ships transporting goods for Spain, see: de la Laurie, Naples, 20 December 1718: AN, Marine, B1, 40, fol. 21․ In the same vein: de Camp, The Hague, 29 December 1718: ibid., fol. 30vi: French complaints of Dutch depredations should be temporarily disregarded, since treating them would hamper Franco-British attempts to lure the Republic into the Quadruple Alliance.

8 See: Chammorel's report, 28 June 1717 on negotiations with James Craggs, Secretary of State for the Southern Department, o.c., fol. $447^{\mathrm{v}}$ : '[...] the crisis where 
In reality, the commercial balance established at Utrecht seemed to be honoured more in the breach than in the observance. ${ }^{9}$ The present article examines the case of the War of the Quadruple Alliance (1718-1720), whereby France and Britain intervened on the side of the Emperor against perceived Spanish aggression in Italy. ${ }^{10}$ This conflict discredits the idea of a 'Second Hundred Years' War' between France and Britain from 1688 to 1815. The French Regent, Philip of Orléans (nephew of Louis XIV), went to war against Louis' own grandson, in alliance with a Protestant Maritime Power. All long-term economic, cultural and strategic interests seemed to pit Versailles and Hampton Court against one another. Yet the execution of the Treaty of Utrecht was a personal priority for both the Regent and George I, whose legitimacy was challenged by the Jacobite cause of the exiled 'King James III', James Francis Edward Stuart.

This article argues in the first instance that the impact of military operations and diplomatic alliances on Mediterranean trade was only superficial, and that Franco-British commercial rivalry was firmly entrenched. French merchants and consuls' complaints read as if the War of the Spanish Succession (1702-1713, which saw France and Spain pitted against the Maritime Powers and the Habsburg Monarchy) was still in train. ${ }^{11}$ The following complaint from the aldermen and deputies

negotiations on Italy are in at present will further prolong the resolutions we had hoped for a long time.' Similar complaints on the breach of the dispositions in the Franco-English trade Convention of Utrecht (11 April 1713, Corps Universel Diplomatique du Droit des Gens (CUD) VIII/1, no. CLII, artt. XVIII-XX): '[...] although the English had insisted the most on phrasing the treaty in these terms, forcing us [France] to derogate to all our established ordinances [...]' (Memorandum of the Council of Commerce, 31 January 1719: AN, Marine, B1, 40, fol. 35 ).

9 See: de Camp, The Hague, 29 December 1718, o.c., fol. 30 ${ }^{\mathrm{r}}$ : Dutch corsairs seize French vessels, 'worth more than two millions [livres tournois]' after the Treaty of Utrecht; 'formally contravening' the trade convention between France and the Dutch Republic. See art. VII, Treaty between Louis XIV and the Estates-General, Utrecht, 11 April 1713, CUD VIII/1, no. CLVII, 378.

10 Robert Phillimore, Commentaries upon International Law, 4 vols, $3^{\text {th }}$ edn (London: Butterworth, 1879-1889), II (1882), pp. 85-110; Núria Sallés, Giulio Alberoni y la Dirección de la Politica Exterior Española después de los Tratados de Utrecht: 1715-1719 (unpublished doctoral thesis, Pompeu Fabra University, 2016).

11 See: Admiral Jennings' complaints of French depredations in the Mediterranean, coupled with the disrespect of neutrality by states such as the Grand Duchy of 
for commerce of Marseille illustrates the underlying tensions between French and British commercial interests, at a time when the Regent and George I combined to advance a common geopolitical goal. British private merchants and warships alike stopped and searched allied vessels:

The English actually have an overt trade in all ports of Spain [...] they bring in all kinds of manufactured goods and food. Since the declaration of War [9 January 1719] [v] His Majesty's subjects have been forbidden access to these advantages [...] their vessels pillaged and searched almost daily, and stopped by those belonging to the English nation without reverence or consideration for the French flag [pavilion]..$^{12}$

In spite of public declarations of war, or the theoretical primacy of a nation's self-preservation over advantages enjoyed by private individuals, the wartime suspension of trade was interpreted restrictively or avoided through indirect trade with neutrals. ${ }^{13}$ Conversely, even between allies, trade remained a zero-sum game of fierce competition. ${ }^{14}$ Partners in a common political undertaking were perceived to be as trustworthy as outside neutrals or enemies, 'exploiting every occasion to thwart and ruin commerce and navigation.' ${ }^{\prime 5}$ According to Clairambault, French consul in Livorno, the reputation of the French nation as an intermediary for maritime transport was at stake - which he viewed as being more important than commercial damage to private owners. If British vessels were implicitly rendered safer, thereby profiting from the British military

Tuscany. John S. Bromley, Corsairs and Navies (London: Hambledon Press, 1987), pp. 234-35.

12 Complaint by the Aldermen and Deputies for Commerce of Marseille, 3 and 8 November 1719: AN, Marine, B1, 36, fols 342 $-42^{\mathrm{v}}$.

13 Eric Schnakenbourg, Entre la Guerre et la Paix: Neutralité et Relations Internationales, XVII $-X V I I I^{e}$ Siècles (Rennes: Presses Universitaires de Rennes, 2013), p. 33. See, in the same vein, the difficulties regarding trade between the Maritime Powers and France during the War of the Spanish Succession: Bromley, pp. 42-72, 213-42 and especially pp. 394-95.

${ }_{14}$ Memorandum by Clairambault (consul in Livorno) to the Regent, 20 January 1719: AN, Marine, B1, fol. 46v . Excessive searches and seizures by France's British ally on French vessels or on those of French trading partners, which 'interrupts Commerce and Navigation.'

15 Clairambault, Livorno, 19 May 1719: AN, Marine, B1, 40, fol. 135. 
fleet's dominance, then France would have few commercial advantages to gain from a war in the Mediterranean. ${ }^{16}$

These general aggressive dynamics should not therefore reverse the intellectual order of priorities. Diplomats emphasised the need to preserve the balance of power first: individual merchants' complaints regarding violations of trade regulations ranked a poor second. Actions by the navy or consuls could only be undone by 'rigorous orders' from London or Paris. 'Respect for treaties and conventions' was subject to the outcome of diplomatic negotiations. ${ }^{17}$

The secondary aim of this article is to show how geopolitical Grand Strategy had repercussions for trade policy and the legal language used to frame it, and, conversely, how a discourse of interdependence and free trade was so evident that all parties used it indiscriminately. Seizures were regularly portrayed as being violations of the 'law of nations'. ${ }^{18}$ Yet individual claims were dependent on the political context, and primarily on the geopolitical changes brought about by the unusual situation of a Franco-British alliance.

\section{INTRICATE CONFLICTS}

The harbours of the Kingdom of Naples daily see Frenchmen in Spanish service $[\ldots]$ of all kinds [...] out of greed, deserters [...] or on their way back to the kingdom after the declaration of war. ${ }^{19}$

Within three years of the final peace treaty of Baden (7 September 1714), Spain invaded the Austrian-controlled island of Sardinia (22 August 1717). The following year, Spanish troops landed on the island of Sicily, then ruled by the House of Savoy (1 July 1718). This was a direct attack on the peace settlement of 1713-1714. The Kingdom of Sardinia had been ceded by Spain to Emperor Charles VI under the

16 See: consul Clairambault complaining on British stubbornness in releasing goods unlawfully seized on French vessels. (Clairambault, Livorno, 12 May 1719: AN, Marine, B1, 40, fols $137^{\mathrm{v}}-38^{\mathrm{r}}$ ).

${ }^{17}$ Clairambault, Livorno, 16 June 1719: AN, Marine, B1, 40, fol. $152^{v}$.

18 See: Portier, Tenerife, 13 May 1719: AN, Marine, B1, 40, fol. 156 (on the conservatory seizure of tobacco stocks belonging to French nationals).

${ }^{19}$ De la Leurie, Naples, 26 September 1719: AN, Marine, B1, 40, fol. 231 
Treaty of Rastatt. The crown of Sicily was now in the possession of Victor Amadeus II of Savoy, again as a result of a Spanish concession..$^{20}$ Philip V claimed that ongoing negotiations between Turin and Vienna to hand Sicily over to the Emperor were a violation of the right of reversion, which he had retained on the occasion of the Spanish-Savoyard peace treaty. ${ }^{21}$ In case the House of Savoy should leave Sicily, the island would revert to the crown of Spain. Yet none of this had been agreed or executed when Spanish troops landed on the island, which was poorly defended by Savoy. ${ }^{22}$ Philip merely acted out of a desire to protect Spanish interests, since the reversion right on Sardinia was worth less than that of Sicily. ${ }^{23}$ The island of Sardinia could act as a hub for a future invasion of Naples or Tuscany, and therefore was of considerable significance to the Spanish government. ${ }^{24}$

Charles VI was at war with the Ottomans in the Balkans at the same time (1716-1718). Consequently, the Emperor had to appeal for external assistance to withstand this Spanish assault on his Sardinian possession. France and Britain were willing to offer this. However, they were not prepared to inflict sanctions on Spain. Philip V and Elisabetta Farnese, along with Cardinal Alberoni, had astutely invoked Italian frustration at Imperial encroachments on princely liberties. ${ }^{25}$ The

20 Elisa Mongiano, 'Universae Europae Securitas': I Trattati di Cessione della Sardegna a Vittorio Amedeo II di Savoia (Turin: Giappichelli Editore, 1995).

21 Considérations sur la Guerre d'Italie ([n.p.]: [n. pub.], [1718]); Treaty of Peace between Philip V and Victor Amadeus of Savoy, Utrecht, 13 August 1713, CUD VIII/1, no. CXLVI, 403, art. VI.

22 Christopher Storrs, War, Diplomacy and the Rise of Savoy, 1690-1720 (Cambridge: Cambridge University Press, 1999), p. 72.

23 Mercure historique et politique, Contenant l'état présent de l'Europe, ce qui se passe dans toutes les Cours, l'Intérêt des Princes, leurs Brigues, \& généralement tout ce quil y a de curieux pour le Mois de Janvier 1719 (The Hague: Les Frères Van Dole, 1719), p. 86. Other motives, such as the arrest of Molinez in the Duchy of Milan, were deployed as casus belli. In the latter case, the Emperor, as Duke of Milan, had respected ecclesiastical privilegium fori, see: Considérations sur la guerre d'Italie, p. 24. Imperial assistance to the Catalan and Majorcan rebellions were complaints dating from the closing years of the War of the Spanish Succession, see: ibid., p. 29.

24 Abbé de Vayrac, État présent de l'Espagne, où l'on voit une géographie historique du Pays, 4 vols. (Amsterdam: Steenhouwer \& Uytwerp, 1719), III, p. 326.

25 Considérations sur la guerre d'Italie, pp. 7, 11, 55. 
Franco-British war aims did not go beyond the restoration of the balance of power on the Italian peninsula. The British Fleet under Admiral Byng quickly destroyed its Spanish counterpart at the Battle of Cape Passaro (11 August 1718). As a result, it was clear that Philip V would no longer enjoy the upper hand in the war. France and Britain had negotiated the criteria for a peace settlement with Charles VI. Austria and Savoy would exchange the kingdoms of Sardinia and Sicily. However, Spain would obtain the promised succession of Philip V's second son, Don Carlos, ${ }^{26}$ to the Duchies of Parma and Piacenza and the Grand Duchy of Tuscany. ${ }^{27}$ Therefore, with the Duke of Savoy moving to Sardinia, the balance of power in Italy would not be endangered. ${ }^{28}$

From the moment Cardinal Alberoni $(1664-1752)^{29}$ was dismissed as Prime Minister (5 December 1719), France and Britain had every

26 The future Charles VII of Naples and Charles III of Spain. Giuseppe Caridi, Carlo III: Un Grande Re Riformatore a Napoli e in Spagna (Rome: Salerno, 2014).

27 Riguccio Galluzzi, Histoire du grand duché de Toscane, sous le gouvernement des Médicis, traduite de l'italien, 9 vols (Paris: Hôtel Serpente, 1782-1784), IX (1784); Jean-Claude Waquet, Le grand-duché de Toscane sous les derniers Médicis: Essai sur le système des finances et la stabilité des institutions dans les anciens États italiens (Romel Paris: Ecole Française de Rome/De Boccard, 1990); Emanuele Salerno, 'Stare Pactis and Neutrality: Grotius and Pufendorf in the Political Thought of the Early Eighteenth Century Grand Duchy of Tuscany', in War, Trade and Neutrality, pp. 188-202. These territories were dynastically linked with Spain through Philip V's second marriage to Elisabetta Farnese, niece of the then-Duke of Parma, Francesco Farnese: see: Christopher Storrs, 'The Spanish Risorgimento in the Western Mediterranean and Italy 1707-1748', European History Quarterly, 62 (2012), 555-77; Christopher Storrs, The Spanish Resurgence, 1713-1748 (Cambridge: Yale University Press, 2017).

${ }^{28}$ Francesca Fausta Gallo, 'Una Difficile Fedeltà: L'Italia durante la Guerra di Successione Spagnola', Cheiron, 39-40 (2004), 245-66; Derek McKay, 'Bolingbroke, Oxford and the Defence of the Utrecht Settlement in Southern Europe', English Historical Review, 86 (1971), 264-84.

29 Émile Bourgeois, La Diplomatie Secrète au XVIII Siècle, Ses Débuts: II. Le Secret des Farnèse, Philippe V et la Politique d'Alberoni (Paris: Armand Colin, 1909); Simon Harcourt-Smith, Cardinal of Spain: The Life and Strange Career of Giulio Alberoni (New York: Knopf, 1955); Pietro Castagnoli, Il Cardinale Giulio Alberoni, 3 vols (Piacenza: Collegio Alberoni, 1929), I; Mil. R. Vesnitch, 'Cardinal Alberoni: An Italian Precursor of Pacifism and International Arbitration', The American Journal of International Law, 8 (1913), 51-82. Alberoni fled to Genoa, where the Republic did not intend to extradite him to Spain, see: Émile Vincens, Histoire de la République de Gènes, 4 vols (Paris: F. Didot, 1842), III, p. 262. 
motivation to restore good relations with the Spanish crown, if only in order to reinstate bilateral trade. ${ }^{30}$ The Parmezan Prime Minister in Madrid was a convenient scapegoat for the French and British courts. Dynastic and domestic considerations could explain this. Philip V, grandson of Louis XIV, was a Bourbon prince. ${ }^{31}$ Philip of Orléans, who acted as Regent during Louis XV's minority (until February $1723)^{32}$ could not afford to alienate the traditionalist factions at court in Paris, and also had to face regional unrest in Brittany. ${ }^{33}$ Moreover, the captains of privately-owned French ships ${ }^{34}$, captains ${ }^{35}$ and sailors were enlisting with Philip $V^{36}$ or were engaged in carrying his troops across the Mediterranean. ${ }^{37}$ When famine struck Majorca, French merchants rapidly provided the island with the necessary grain. ${ }^{38}$ After issuing a first recalling Ordinance, ${ }^{39}$ the Regent considered it

30 Act of Accession to the Quadruple Alliance by Philip V, accepted by the signatory powers to the Treaty of London, The Hague, 17 February 1720, CUD VIII/2, no. XI, 26.

31 La Présence des Bourbons en Europe, $X V I^{e}-X X I^{e}$ Siècle, ed. by Lucien Bély (Paris: Presses Universitaires de France, 2003).

32 Alexandre Dupilet, La Régence Absolue: Philippe d'Orléans et la Polysynodie (Seyssel: Champ Vallon, 2011).

${ }^{33}$ E.g. mobilising the British fleet to patrol off Brittany: Stair to Craggs, Paris, 31 May 1719: NA, SP, 78, 164, fol. 86 ; Pierre de La Condamine, Pontcallec: Une Etrange Conspiration au Cour de la Bretagne ([Mayenne]: Y. Floc'h, 1988).

34 E.g. Circular by the Regent to enjoin French privateers under the Spanish flag to cease their 'intolerable' activities, or accept the consequences of treatment as 'deserters'. AN, B1, Marine, 40, fols 45 $-46^{\mathrm{r}}$.

35 Barber (Cadiz), 9 September 1719: AN, Marine, B1, 40, fol. $229^{\mathrm{r}}$.

36 See: report of 5 December 1717, Barcelona in AN, Marine, B1, 32, fol. $5^{\mathrm{v}}$. French captains from Toulon participated in the expedition on Sardinia under Spanish pavilion, and hoisted the French flag again afterwards. See: report by de Varennes (Alicante) on French sailors serving on a Spanish man of war, captured by the British fleet in a fight off the Spanish coast (AN, Marine B1, 40, fol. 35).

37 Aubert (Genoa), 3 January 1719: English complaints on Spanish troops transported aboard two French vessels. AN, Marine, B1, 40, fol. 20v.

38 Nieulon fils, Mallorca, 17 August 1719: AN, Marine, B1, fol. 214.

39 Ordinance of Louis XV enjoining his subjects in Spain to come back to France immediately after publication, yet granting a delay of six months to all French merchants presently in Spain to stay there for six more months, in order to withdraw, sell or transport their goods and properties, Paris, 10 January 1719; Ordinance of Louis XV permitting Spanish subjects to stay in France for six months, 
advantageous to grant amnesty to disobedient subjects. ${ }^{40}$ Finally, from a French perspective, the Emperor could not be allowed to become too powerful. The peace settlements of 1713-1714 aimed to establish and to preserve an equitable repartition of territories in Europe between the two main rival houses: those of Habsburg and Bourbon. ${ }^{41}$ France and Britain acted as mediators between Charles VI and Philip V. ${ }^{42}$ Neither Philip or Charles had accepted the idea of a partition of the Spanish composite monarchy. Accordingly, they demanded a general conference to conclude a final peace treaty between them and to implement all the terms of the multilateral agreement concluded in London on 2 August 1718 N.S., known as the 'Quadruple Alliance'. ${ }^{43}$

During the military operations, trade in the Mediterranean was a point of significant interest. Firstly, although Italy had long been an object of external powers' political appetites, and was 'covered with foreign troops', this did not imply that the peninsula had fallen into economic oblivion. ${ }^{44}$ As Pietro Tosini's 1718 pamphlet - defending Italy's liberties against ungrateful and avaricious neighbouring peoples - put it, 'Barbarous Nations have not been humanised but through the Italian trade', spreading 'arts, sciences and the most considerable advantages'

in order to sell or transport their belongings, Paris, 10 January 1719; Ordinance of Louis XV permitting his subjects to travel to collect their properties and goods in Spain, to bring them back to the Kingdom within six months from 10 January, Paris, 6 March 1719.

${ }^{40}$ Chavigny, Genoa, 4 October 1719: AN, Marine, B1, 40, fol. 289. See Draft ordinance to facilitate the return of Frenchmen in the Kingdom, of any profession, after leaving for Italy or other states, AN, Marine, B1, 40, fols $227^{\mathrm{r}}-29^{\mathrm{r}}$.

${ }^{41}$ Frederik Dhondt, 'From Contract to Treaty: The Legal Transformation of the Spanish Succession, 1659-1713', Journal of the History of International Law - Revue d'Histoire du Droit International, 13 (2011), 347-75; Jean Bérenger, 'Le Conflit entre les Habsbourg et les Bourbons (1598-1792)', Revue d'Histoire Diplomatique, 116 (2002), 192-232.

42 Considérations sur la guerre d'Italie, p. 18.

43 Treaty of Alliance between Charles VI, Louis XV and George I, London, 2 August 1718, CUD VIII/1, no. CCII, 531. France, Britain and the Emperor were the initial parties to the agreement. Savoy adhered in November 1718, but the fourth place was destined for the Dutch.

${ }^{44}$ Pietro Tosini, La liberté de l'Italie demontrée à ses princes et à ses peuples, traduite de l'Italien (Amsterdam: Steenhouwer \& Uytwerf, 1718), p. 3. 
across Europe. ${ }^{45}$ Secondly, both the bilateral Franco-Spanish and Anglo-Spanish trade flows were considerable. ${ }^{46}$ Outside of Spain itself, the de jure suspension of commercial relations was often accompanied by confiscations throughout the Spanish commercial empire. ${ }^{47}$

\section{PHILIP V, OR THE COMMERCIAL POLITICS OF 'DIVIDE ET IMPERA'}

As the war progressed from the summer of 1718 to the winter of 1719-1720, its outcome was predictable but far from certain. The main ministerial protagonists, James, Earl of Stanhope (effectively Prime Minister of Great Britain) ${ }^{48}$ and the abbé Guillaume Dubois (French secretary of state for foreign affairs, and the most influential member of the French government), ${ }^{49}$ were constantly caught between hopes

45 Ibid., p. 9: 'Les Nations Barbares n’ont été humanisées que par le Commerce des Italiens, et ne se sont enrichies que des bienfaits dont ils ont été prodigues envers elles.'

46 Considérations sur la guerre d'Italie, p. 42. Not to mention direct debts payable in France, e.g. 'Cardinal Alberoni declared only recently to the Duke of Saint Aignan that the King of Spain would pay no debt whatsoever as long as he would be at war [...]' (Catalan, French informant in Madrid to the Marine Council, 6 December 1717: AN, Marine, B1, 32, fol. $1^{\mathrm{r}}$. See complaints of the violation of French privileges (quartering of soldiers, De Moy, Barcelona) in: ibid., fol. $3^{\text {r }}$. Ralph Davis, 'English Foreign Trade 1700-1774', Economic History Review, 15 (1962), 285-303 (pp. 287-88, 293, 301-03). J.O. Maclachlan, Trade and Peace with Old Spain, 1667-1750 (Cambridge: Cambridge University Press, 1940); François Crouzet, 'La Rivalité Commerciale Franco-Anglaise dans l'Empire Espagnol, 1713-1789', Histoire, Économie et Société, 31 (2012), 19-29. Crouzet's article estimates French exports to Spain at 19,3 million livres tournois for the years from 1716 to 1720 . British exports would have been worth around 10,3 million.

47 See: report from Cadiz, 30 Oct 1717: Diego Navarro, intendant for tobacco, had seized 200.000 piastres belonging to the French 'nation'. The damage to French interests was even more important since 'this judge has neither credit nor money'. (AN, Marine, B1, 32, fol. $7^{\mathrm{r}}$ ).

48 Basil Williams, Stanhope: A Study in Eighteenth-Century War and Diplomacy (Oxford: Clarendon Press, 1932).

49 Alexandre Dupilet, Le Cardinal Dubois: Le Génie Politique de la Régence (Paris: Tallandier, 2015); Émile Bourgeois, La Diplomatie Secrète au XVIII Siècle, Ses Débuts: I. Le Secret du Régent et la Politique de l'Abbé Dubois (Triple et Quadruple Alliance) (1716-1718) (Paris: Colin, 1909); Émile Bourgeois, La Diplomatie Secrète au XVIII Siècle, Ses Débuts: III. Le Secret de Dubois, Cardinal et Premier Ministre (Paris: A. Colin, 1910); Guy Chaussinand-Nogaret, Le Cardinal Dubois, 1656-1723 
of success and fears of failure, providing an insight into both men's domestic political position. They had each built their careers by gradually discarding opposing factions. As the outcome of military operations was always uncertain, their letters incorporated all possible alternatives, and also reveal the structure and the course of international crises. Spain tried to play both mediators against each other, by applying different measures to similar situations. The Spanish ambassador in London, Monteleón, ${ }^{50}$ intimidated the directors of the South Sea Company. ${ }^{51}$ As a result, British merchants and traders feared confiscations, ${ }^{52}$ and hid their assets in storehouses 'of the Flemish or French' nations. ${ }^{53}$ French merchants, by contrast, had obtained a decree from Philip V dated 9 November 1718, whereby their effects were safeguarded from confiscation, ${ }^{54}$ and their vessels rendered immune from Spanish searches. ${ }^{55}$ This served to quell a genuine fear in France, due to the potential economic consequences of a rupture with Spain. ${ }^{56}$ Nonetheless, this fear was common to both belligerents. Philip V desired to let trade continue, ${ }^{57}$ if only for the necessary imports of goods not produced

ou une Certaine Idée de l'Europe (Paris: Perrin, 2000); Frederik Dhondt, 'Kardinaal Dubois door Hyacinthe Rigaud (1723): Een Insider's View op een Bibliotheek van de Macht in de Grand Siècle', Pro Memorie: Bijdragen tot de Rechtsgeschiedenis der Nederlanden, 16 (2014), 45-54.

50 Isidro Casado y Rosales, marquis de Monteleon (1663-1733). Ambassador in Rome 1708-1709, third Spanish plenipotentiary at Utrecht, ambassador in London 1714. Sicilian native in Spanish service. Didier Ozanam and Denise Ozanam, Les Diplomates Espagnols au XVIII Siècle (Madrid/Bordeaux: Casa de Velázquez/Maison des Pays Ibériques, 1998), p. 217.

51 Robert R. Mcjimsey, 'Shaping the Revolution in Foreign Policy: Parliament and the Press, 1689-1730', Parliamentary History, 25 (2006), 17-31 (p. 27).

52 E.g. immediate seizure of all British goods on the Canaries, inspiring fear among the inhabitants, 'whose only richess consists in their wines, the majority of them destined for the British market' (Portier, Tenerife, 24 February 1719: AN, Marine, B1, 40, fol. $112^{\mathrm{r}}$.

53 AN, Marine, B1, 32, fol. 449.

54 Brigodet de Varennes, Alicante, 28 November 1718: AN, Marine, B1, 40, fol. $2^{\text {r }}$.

55 de l'Epinard, Messina, 17 December 1718: AN, Marine, B1, 40, fol. $47^{\mathrm{v}}$.

56 'The French had for 20 million livres tournois in Spain. If they were to be confiscated, this would inflict a terrible blow on the Regent, who needed time to withdraw them' (Stair to James Stanhope, Paris, 5 October 1718: NA, SP, 78, 162, fol. 207')

57 Royal Decree by Philip V, Madrid, 10 February 1719, quoted in the report 
in his realms, ${ }^{58}$ such as textiles. ${ }^{59}$ However, this offers us a further possibility to contrast Spanish complaisance and generosity towards French merchants with the comparatively dominant and aggressive British stance. As a consequence, from January 1719, Philip decided to reinforce the Spanish party in France and to put pressure on the Regent to withdraw from the coalition.

The case of Messina is of particular interest. Spanish troops landed on the island of Sicily on 1 July 1718. Fifteen months later, Imperial troops under Mercy d'Argenteau (1666-1734) reconquered almost the whole kingdom, in October 1719. Already in January 1719, de l'Epinard had reported that the Spanish commander, Spinola, had barely enough supplies for a month. However, in the meantime, French merchants provided clothing and tents, imported from Nîmes and Anduze, to the army of Jean-François de la Bette, Marquis de Lede (1668-1725), commander of Spanish forces in the Mediterranean and also Philip V's appointee as Viceroy of Sicily. ${ }^{60}$ The negotiations for these supplies had been concluded before January 1719 and the French declaration of war on Spain. The arrangement could thus be carried out. Moreover, the Regent considered Sicily to be a possession of the Emperor, even before the treaty of exchange with Sardinia had been signed. This was on the basis of Savoy's accession to the Quadruple Alliance, article VI of which foresaw the Spanish renunciation of the right of reversion on Sicily and its transfer to the Austrian Habsburgs. ${ }^{61}$

of Nieulon fils, Mallorca, 18 February 1719: AN, Marine, B1, 40, fol. 84v. E.g. French vessels regularly arriving in Mallorca with grains, whereas military operations on Spanish soils had already begun by January 1719 (Nieulon fils, Mallorca, 9 July 1719: AN, Marine, B1, 40, fol. 199').

58 Vayrac, III, p. 317. Attempts to set up manufacturing industries with labourers from Holland or France illustrate a desire on the part of Alberoni and the Duke of Ripperda. See also: Davis, 285-303 (p. 295).

59 See: Aubert, Genoa, 16 May 1719: AN, Marine, B1, 40, fol. 136 , on a Neapolitan corsair stopping a French merchant vessel sailing from Saint-Tropez to Barcelona carrying 1300 Spanish uniforms. The French consul hoped these goods could be qualified as ordinary trade stock, since they had been exempted in the Franco-British Treaty of Commerce concluded at Utrecht (art. XII, CUD VIII/1, 348).

60 de l'Epinard, Messina, 10 March 1719: AN, Marine, B1, 40, fol. 103'.

${ }^{61}$ Act of Paris, 8 October 1718; Act of London, 8 November 1718; Act of Vienna, 2 November 1718, CUD VIII/1, no. CCVI, 549. 
News gradually reached Paris that the Spanish authorities were seizing stocks or compelling their sale to the Spanish crown at a lower price. Spanish promises were thus seen as unreliable. ${ }^{62}$ The Council of the Marine asked French consuls in Spain to encourage their merchants to evacuate and repair to France as soon as possible. ${ }^{63}$ As the war effort strained Spanish resources, higher taxation ${ }^{64}$ (or confiscations of French vessels) became inevitable. ${ }^{65}$ As the French army, under the Duke of Berwick, invaded Guipuzcoa and Galicia, the Spanish governor accused French merchants who brought their belongings to safety of insulting the trustworthiness of Philip V's decree, which ostensibly protected them. ${ }^{66}$ Meanwhile, in the Mediterranean, Admiral Byng's fleet regularly harassed French commercial vessels bound for Sicily or Sardinia, declaring all of them suspect. This reflected the perceived favouritism with which Spain was treating France. ${ }^{67}$

\section{PRIVATEERING BETWEEN OUTSOURCED PUBLIC AUTHORITY AND INDIVIDUAL GREED}

Private merchants of France's allies treat the King's subjects as enemies and entirely ruin their commerce and navigation in the Mediterranean. ${ }^{68}$

Privateering can be seen as an aspect of states' external military power, or at least the power to harm enemy trade. ${ }^{69}$ Military vessels could of
62 Portier, Tenerife, 24 February 1719, o.c., fol. $112^{\mathrm{r}}$.
63 E.g. Domas, Cartagena, 17 April 1719: AN, Marine, B1, 40, fol. 139'.
${ }^{64}$ Du Pin, Alicante: AN, marine, B1, 40, fol. $130^{\mathrm{v}}$.
65 Barber, Cadiz: 21 March 1719: AN, Marine, B1, 40, fol. 126v'.
66 Barber, Cadiz, 19 May 1719: AN, Marine, B1, 40, fol. 148.
67 Clairambault, Livorno, 16 June 1719, o.c., fol. 151v; De la Leurie, Naples, 15 May 1719: AN, Marine, B1, 40, fol. 140v . Another example in his letter dated 23 May 1719 (ibid., fol. 141'): a French vessel left Palermo after a commercial mission. It drifted off in a storm near Milazzo and had to look for Spanish help. Yet, 'German' (Austrian) forces intercepted it off the coast of Naples, jailing the crew. Viceroy Daun promised to release them, but judicial proceedings in Naples dragged on and on.

68 De la Chausse, Rome, 14 November 1719: AN, Marine, B1, fol. 296r.

${ }^{69}$ Louis XIV urged James II to issue letters of marque to Jacobites during the Nine Years' War, in view of privateering's strategic impact; see also Vauban's Mémoire sur la Caprerie. In the Jacobite case, privateering was based on 'the right of a deposed king to wage war' and thus constituted a means of prolonging a civil war on the high seas. 
course conduct search operations, either as part of the fleet patrolling the Mediterranean, ${ }^{70}$ or from bases such as Port Mahon or Gibraltar, which Britain had captured during the War of the Spanish Succession and had retained under the Treaty of Utrecht. ${ }^{71}$ However, beyond the limitations of the Royal Navy's actions and responsibilities, privateers could constitute an effective alternative. Private individuals exercised public authority, stimulated by potential private profits in the name of a public cause. ${ }^{72}$ The rules governing their conduct were derived from public law, and not from private law. ${ }^{73}$ Letters of marque were granted irrespective of the recipients' nationality. Catalans, subjects of the King of Spain, could harass French vessels in the free port of Livorno, ${ }^{74}$ acting as privateers from Naples in the name of Emperor Charles VI,

See: Bromley, pp. 140, 165 and 217. Jacobite and French privateering accompanied the failed attempt by Forbin to bring the Old Pretender ashore in Scotland in March 1708, a movement which caused a genuine 'run on the Bank of England'. Bromley abundantly illustrated the quasi-global impact of privateering during the War of the Spanish Succession. Furthermore, taxes or duties due to the state (e.g. the Zealand public authorities or the Amiral de France) generated supplementary benefits for the state in encouraging a system of privateering. In Britain, the Lord High Admiral surrendered his tenth (10\%) of the net property (i.e. after payment of all dues and charges) of a prize to the Crown, which in turn abandoned this further claim altogether in the 1708 Prize Act (Bromley, p. 464).

${ }^{70}$ E.g. French accusations against admiral Byng 'by the profit he reaps from vexations' (Clairambault, Livorno, 20 January 1719, o.c.

${ }^{71}$ Complaints by de Moy, Barcelona, 4 February 1719: AN, Marine, B1, 40, fol. $49^{\mathrm{v}}$.

72 Gary M. Anderson and Adam Gifford Jr., 'Privateering and the Private Production of Naval Power', Cato Journal, 11 (1991-1992), 99-122.

73 Cornelius Van Bynkershoek, Quaestionum iuris publici libri duo, trans. by Tenney Frank (Washington: Carnegie Institute, 1930 [1737]), p. 104. Nevertheless, the business partnerships and ventures set up to finance a privateering expeditions fall under private law, see: Bromley, pp. 64-65. Investment in privateering and maritime transport was widespread in Britain, and concerned countryside landowners ('from Kent to Scotland') as well as traditional merchants in trading ports. Various motivations led to activity in the privateering 'business', ranging from 'speculative investment which could bring windfall profits', over 'an outlet for resources otherwise damned up by war' to 'humbly [...] an expression of local poverty', see: Bromley, p. 215.

74 Wolfgang Kaiser and Guillaume Calafat, 'Violence, Protection and Commerce: Corsairing and Ars Piratica in the Early Modern Mediterranean', in Persistent Piracy: Maritime Violence and State Formation in Global Historical Perspective, ed. by Stefan Amirell and Leos Müller (London: Palgrave, 2014), pp. 69-92 (p. 74). 
who had set up his court in Barcelona during the War of the Spanish Succession! $!^{75}$ In essence, the Neapolitan authorities granted privateering commissions to anybody, without even asking for a proper guarantee. Penniless Catalans and Majorcan refugees eagerly enlisted, hoping to re-establish themselves by terrorising the Mediterranean. ${ }^{76}$

Courts and tribunals could determine the legality of seizures effected in national ports. ${ }^{77}$ Neutral vessels were not immune from searches. 'Free ship, free goods' could only be a prudent wish. ${ }^{78}$ Trade politics in terms of the customs established by reciprocity seemed impossible between strong and weaker parties. ${ }^{79}$ Conventional or doctrinal definitions of contraband were vague, privileges precarious, and the perpetual object of a political rapport de force. References to general principles served to encourage the Regent to take diplomatic action, rather than to place his trust in judicial institutions controlled by another power. De la Leurie's description of an incident in December 1718, before the French declaration of war, is telling:

[...] commerce not having been interrupted, the French could load and navigate for any destination without being arrested [...] If there had to come about a rupture [between England and France], there were Treaties and Laws to be followed, ordering French vessels to be released. ${ }^{80}$

Even cargoes of grains, sugar or French cheese were stopped! ${ }^{81}$ One might imagine that privateers should stop only 'enemies, and not

75 Clairambault, Livorno, 2 June 1719: AN, Marine, B1, 40, fol. $143^{\text {r }}$.

76 De la Leurie, Naples, 23 June 1719: AN, Marine, B1, 40, fols 161 ${ }^{\mathrm{v}}-62^{\mathrm{r}}$.

77 AN, Marine, B1, 36, fol. $132^{\mathrm{r}}$.

${ }^{78}$ E.g. de Rochefort, Stockholm, 13 January 1719: AN, Marine, B1, 40, fol. 41': Charles XII of Sweden urges his nations' privateers to respect the rights of neutrals and limit their actions to the country's enemies. On the emergence of this principle, see: Schnakenbourg, p. 97.

79 Koen Stapelbroek, 'Between Utrecht and the War of the Austrian Succession: The Dutch Translation of the British Merchant of 1728', History of European Ideas, 40 (2014), 1026-43 (p. 1040). Ollivier, Palermo, 18 August 1719: AN, Marine, B1, 40, fol. $219^{v}$.

${ }^{80}$ De la Leurie, Naples, 20 December 1718: AN, Marine, B1, fol. $22^{\text {r }}$.

${ }^{81}$ Clairambault, Livorno, 26 May 1719: AN, Marine, B1, 40, fol. 139vi de la

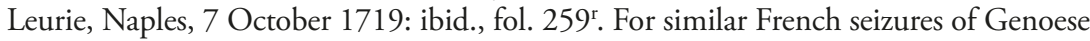
neutral cargoes set for enemy-controlled Barcelona or Lisbon during the War of the Spanish Succession, see: Bromley, p. 235. 
friends' ${ }^{82}$ If principles or past agreements were to have any value, they needed to be reaffirmed time and time again: 'If we do not oppose these kinds of acts, the [French] nation will be exposed daily to new insults, and eventually to the loss of her privileges. ${ }^{83}$ The law of nations in general was thus seen as insufficient to provide individuals with efficient legal protection. ${ }^{84}$ Only bilateral, repeatedly asserted privileges could do so.

In practice, belligerents looked for enemy goods on any ship. ${ }^{85}$ 'Contrary to all treaties [...] the 'slightest indication of any merchandise's pertaining to a subject of the King of Spain' was enough to trigger avaricious British marines or privateers to search for and to confiscate the said merchandise. ${ }^{86}$ This intimidated merchants from the Languedoc and Provence. In Livorno, meanwhile, the British consul was withholding French assets, 'violating the treaties of Utrecht and the most exact justice'. ${ }^{87}$ British subjects sailed under Spanish commissions, harming French trade. Blank Spanish passports were auctioned at the London Stock Exchange, having been gladly distributed by Philip V. ${ }^{88}$ Nonetheless, the British fleet at times correctly applied the law of nations with regard to privateering. ${ }^{89}$ Although the Regent did not want to endanger

82 Bynkershoek, p. 111.

${ }^{83}$ Portier (Tenerife), 24 February 1719, o.c., fol. $112^{\mathrm{v}}$.

${ }^{84}$ Robert Kolb, 'The Protection of the Individual in Times of War and Peace', in Oxford Handbook of the History of International Law, ed. by Bardo Fassbender and Anne Peters (Oxford: Oxford University Press, 2012), pp. 317-337 (p. 319); Dominique Gaurier, Histoire du Droit International (Rennes: Presses Universitaires de Rennes, 2014), p. 810.

85 AN, Marine, B1, 40, fol. $1^{\mathrm{r}}$. Report by Partyet (Cadiz) on Spanish practices of indiscriminately searching English and other nations' vessels for English goods. Clairambault, Livorno, 20 January 1719) accused the English consul in Livorno of blackmail. He would have demanded a fixed fee of $2 \%$ on French assets in exchange of a certificate of property, as immunity against searches conducted by Admiral Byng. In a similar case, whereby two French vessels were accordingly unjustly retained by Admiral Byng, the English consul demanded a 5\% fee, 'vexation inouie' (Clairambault, Livorno, 7 April 1719: ibid., fol. 113 ${ }^{\mathrm{v}}$ ).

${ }^{86}$ De Moy, Barcelona, 4 February 1719, o.c., fol. 49.

87 Clairambault, Livorno, 15 March 1719: AN, Marine, B1, fol. 95v.

${ }^{88}$ Chammorel, London, 12 November 1719: AN, Marine, B1, fol. 271v; Barber, Cadiz, 2 September 1719: ibid., fol. $263^{\mathrm{v}}$.

89 De la Leurie, Naples, 4 April 1719: AN, Marine, B1, fol. 118 . The French vessel Nostre Dame left Palermo for Barcelona carrying correspondence (among which 
his diplomatic relationship with Britain, he issued a protectionist ordinance on 10 July 1719, enjoining the King's subjects to only entrust goods to vessels under the French flag, and to return home. ${ }^{90}$

\section{NEAPOLITAN AND BRITISH DISORDERS}

How much are we hurt by those petty corsairs under the Imperial flag? ${ }^{91}$

The Archives Nationales in Paris contain numerous complaints of private merchants concerning brigandage in the Mediterranean. Perhaps surprisingly, Italian privateering posed a more significant threat than was the case for Spain, a belligerent. The Kingdom of Naples - under the sovereignty of Charles VI, an ally of France and Britain - was described as the most dangerous nest of corsairs. The Austrian Habsburg dynasty had controlled Naples since Joseph I's troops had driven out the Spanish forces of Philip V in 1707. Wirich Philipp, Count of Daun (1669-1741) acted as its governor. The Kingdom did not return to Spanish hands until 1733-1734. ${ }^{92}$ Privateering activities could of course be explained by the ongoing Austro-Ottoman war, which lasted until the peace of Passarowitz (21 July 1718). ${ }^{93}$ To the extent whereby French vessels were transporting Turks, or goods for trading in the Levant, Charles VI's corsairs could intercept part of the Ottoman army's logistical support.

a letter to Philip V), but was caught in bad weather and had to divert to Cape Passaro, where the British man o' war The Grafton intercepted her. The crew and captain were released and given back their belongings and money in Naples.

90 Ordinance by Louis XV, executing those of his predecessor issued on 7 January 1689 and 5 April 1713, forbidding all subjects resident in the Levant, Barbary and the ports of Italy, to embark goods on alien vessels not sailing under the French flag, Paris, 10 July 1719.

${ }^{91}$ Regent to Dubois, 7 August 1719: AN, Marine, B1, 40, fol. 192v.

92 Angelantonio Spagnoletti, 'Il Dibattito Politico a Napoli sulla Successione di Spagna', Cheiron, 39-40 (2004), 267-310; Franz Pesendorfer, Österreich-Grossmacht im Mittelmeer? Das Königreich Neapel-Sizilien unter Kaiser Karl VI (1707/20-1734/35) (Vienna: Böhlau Verlag, 1998); Guido Quazza, Il Problema Italiano e l'Equilibrio Europeo, 1720-1738 (Turin: Deputazione Subalpina di Storia Patria, 1965).

93 Peace Treaty between Charles VI, Sultan Ahmet and the Republic of Venice, Passarowitz, 21 July 1718, CUD VIII/1, no. CXIX, 520. 
However, in many cases the Neapolitan privateers acted outside any legal framework, often to 'pillage the most valuable goods' from passing vessels, ${ }^{94}$ or to unjustly retain the Sultan's subjects after peace had been concluded, 'against all laws of nations'.$^{95}$ In the case of the ship-owner Moret, who had been captured by the Neapolitan corsair Palombo, the French resident in Livorno complained that the latter had searched the vessel and confiscated part of the cargo 'without the slightest pretext'. Palombo conducted the vessel to Civitavecchia in the Papal States, but neither Pope Clement XI (embroiled with Spain) nor his officers manifested impartiality. ${ }^{96}$ In another incident, the French merchant Magnan sailed from Calabria to Naples on behalf of Genoese clients, but was caught by a Neapolitan privateer who argued that his cargo was to be declared 'de bonne prise' on the basis of Spanish cargo bills for an earlier voyage to Tenerife. The Tartanne, a vessel owned by the French privateer Martinenq, was seized by a Neapolitan corsair and released again, save for part of its cargo supposedly destined for Spain as contraband. ${ }^{97}$ The goods were subsequently sold off to British tradesmen, in violation of the Quadruple Alliance between the Emperor, France and Britain. ${ }^{98}$

As the Emperor was able to withdraw his troops from the Balkans in order to face the Spaniards in Sicily, Daun ordered the confiscation of any vessel capable of transporting troops, including those armed by subjects of allied powers, such as France. ${ }^{99}$ France and Austria agreed on mutual regulations concerning seizures, rendering the latter merely conservatory in case of doubt. ${ }^{100} \mathrm{~A}$ French vessel containing 600 barrels of powder was captured by a Neapolitan corsair off Corsica. Its listed destination was Malta. The case was solved by the Emperor's envoy Maricon in Genoa.

94 De la Leurie, Naples, 14 March 1719: AN, Marine, B1, 40, fol. 110r.

95 Ibid. The Regent insisted that 'no trial whatsoever' should take place and called for the immediate release of the Sultan's subjects.

${ }^{96}$ Report by Clairambault from Livorno, 17 June 1717: AN, Marine, B1, 32, fols $503^{\mathrm{r}}-03^{\mathrm{v}}$. See also: de la Leurie, Naples, 13 December 1718: AN, Marine, B1, 40, fol. $16^{\mathrm{v}}$.

${ }^{97}$ Ibid., report by Nieuton, Mallorca, 17 December 1718 .

98 AN, Marine, B1, 40, fol. $36^{\mathrm{r}}$.

99 De la Leurie, Naples, 14 February 1719: AN, Marine, B1, 40, fol. $79^{\mathrm{r}}$.

100 Coutlet, Genoa, 28 March 1719: AN, Marine, B1, 40, fol. 99'; Ibid., 10 April 1719: AN, Marine, B1, 40, fol. 113․ 
He agreed in principle to release the French vessel. Yet, while the ammunition and the bills of cargo were being verified in Genoa, the French captain had to sail to Naples in order to transport troops for Daun.

Neapolitan seizures were transferred to Jean Baptiste du Bourg (1690-1728), the French resident in Vienna, who presented these cases to the Imperial court. ${ }^{101}$ Unfortunately, Emperor Charles VI in turn referred all such cases to the Spanish Council, which was packed with his personal creatures, ${ }^{102}$ in a manner reminiscent of his brief reign in Spain: 'The Neapolitans are des gens ramassez, who cannot be restrained by any rule of law, yet they are protected by these people, who will never let them give back what they have taken. ${ }^{103}$ At the peak of British depredations, Admiral Byng's practices were seen as inspiration for the disorderly behaviour of Neapolitan corsairs! ${ }^{104}$ On one occasion in 1719, corsairs from Naples seized a Spanish ship carrying diplomatic correspondence from Venice and handed it over to the British fleet off the coast of Sicily, in order to get their share of the sale. ${ }^{105}$ Whoever came across their path was a possible target. The protection of the corsair Palombo was more effective than the Neapolitan or Imperial court's desire for justice. French consuls repeatedly insisted that the Neapolitan magistrates took a personal interest in every privateering commission they delivered. ${ }^{106}$ One of the detainees died 'a death of misery'. Palombo's protectors, as de la Leurie insinuated, had received their share of his bounty. ${ }^{107}$ This did not imply that all French cases were lost, e.g. that of Arnauld, who obtained the restitution of his

101 Du Bourg, Vienna, 25 April 1719: AN, Marine, B1, 40, fol. 102 .

102 Virginia León Sanz, Carlos VI: El Emperador que no pudo ser Rey de España (Madrid: Aguilar, 2003).

103 Du Bourg, 25 April 1719, o.c., fol. $102^{\mathrm{v}}$.

104 Aubert, Genoa, 27 June 1719: AN, Marine, B1, 40, fol. 188': '[...] the Neapolitans, following the example of the English, use any possible act of power to interrupt French trade and navigation [...]'.

105 de l'Epinard, Messina, 3 March 1719: AN, Marine, B1, 40, fol. 110v. The Spanish captain was jailed by the British, who accused him of negligence. In their eyes, he should have thrown the diplomatic papers overboard to prevent their capture. 106 de la Leurie, Naples, 13 June 1719, o.c., fol. 162 : '[...] les corsaires sont protegez par des ministres qui sont mesme interessez sous main dans les armemens, de sorts qu'il est impossible d'avoir aucune raison de leurs Brigandages [...]'.

107 De la Leurie, Naples, 28 March 1719: AN, Marine, B1, 40, fol. 114v. 
vessel, as well as compensation for the harm inflicted by a Neapolitan corsair, by sentence of the Royal Chamber of Naples. ${ }^{108}$ Outside these intricate networks of reported Neapolitan corruption, Imperial envoys tried to bring their unruly subjects to reason, e.g. enjoining them to appear before local judges in Genoa, ${ }^{109}$ or offering compensation to wronged merchants for damage caused by Italian privateers. ${ }^{110}$ In Spain's case, the use of private agents to protect the colonial empire is a familiar topic to economic and political historians. ${ }^{111}$ Lacking the top-down military means to exclude foreign merchants, private help could fill the gaps. ${ }^{12}$ Disregarding their nationality, even British subjects were reported to have served as privateers for Philip V, thereby damaging the trade of their own compatriots. ${ }^{113}$ Meanwhile, building up a stronger centralised system of government, while embracing mercantilism and protectionist policies, would allow the Spanish crown to better exploit its commercial assets. ${ }^{114}$ During an armed conflict, the ranks of Spanish privateers could be reinforced by private persons, subjects of the Kings of France or Britain, or of the Emperor. ${ }^{115}$

108 Reported by de la Leurie, 5 August 1719: AN, Marine, B1, 40, fols $207^{\mathrm{v}}-08^{\mathrm{r}}$. The presence of corruption in political affairs was not exceptional in the early modern period, where private and public interest were often insufficiently distinguished, see: Aaron Graham, Corruption, Party, and Government in Britain, 1702-1713 (Oxford: Oxford University Press, 2015); Peter R. Campbell, Power and Politics in Old Regime France, 1720-1745 (London: Routledge, 1996); Niels Grüne and Simona Slanička, eds, Korruption: Historische Annäherungen an eine Grundfgur politischer Kommunikation (Göttingen: Vandenhoeck \& Ruprecht, 2010). However, practices in Naples seemed to have come across as particularly striking.

109 Aubert, Genoa, 27 June 1719, o.c., fol. 156v.

110 Aubert, Genoa, 13 June 1719, AN, Marine, B1, fol. 147v.

111 Philip Woodfine, Britannia's Glories: The Walpole Ministry and the 1739 War with Spain (Woodbridge: Royal Historical Society, 1998); Victoria Stapells Johnson, Corsairs of Santo Domingo: A Socio-Economic Study, 1718-1779 (unpublished master thesis, University of Ottawa, 1985).

112 E.g. French vessel seized off the coast of Malaga, 14 March 1719 (report by Fleury de Vareilles: AN, Marine, B1, 40, fol. 92v).

113 Report by le Bailly Lorenz, Florence, 3 March 1719: AN, Marine, B1, 40, fol. 83.

114 Vayrac, III, pp. 312-18.

115 E.g. the case of Le Brun, armator from Toulon, who took a French Pink out of the port of Livorno (Clairambault, Livorno, 31 March 1719: AN, Marine, B1, 40, fol. 104r). Le Brun was broke and had only himself to hold accountable for his 
These search operations were evidently hotly disputed, as were those of the British concerning the transport of Spanish contraband on French vessels in the War of the Quadruple Alliance. ${ }^{116}$ The Anglo-French Treaty on Trade and Commerce concluded in Utrecht (but never ratified for the core articles) ${ }^{117}$ contained an article limiting mutual searches to those carried out in pursuit of strict contraband. ${ }^{118}$ The British fleet, however, did not respect this when patrolling the Mediterranean. The British consul in Livorno even declared the Treaty of Commerce 'ridiculous'. ${ }^{119}$ No 'free ships, free goods' principle was applicable to French vessels. ${ }^{120}$ Even carriages of salted meat, 'goods declared free under the Treaty of Utrecht', ${ }^{121}$ destined for Malta were stopped and seized, under suspicion of being destined for Spanish-occupied Sicily. ${ }^{122}$ In one specific case, the English captain and consul in Livorno blackmailed the French owner, asking for 200 pistoles before he would release the vessel. The crew were molested, kicked, and assaulted with lashes and swords.

Some practical influence on local case law could be useful, as stated by the Council of Commerce in the case of Naples:

[...] no expenditure is more useful for the navigation of His Majesty's subjects than the annual gratification of 150 piastres paid to the judge responsible for adjudicating the seizures of the French nation, who always ranks among the most prominent ministers of the Country [Naples] [...] with the necessary credit and authority to protect and give justice to the French and maintain them in their privileges. ${ }^{123}$

crimes (Clairambault, 12 May 1719, o.c., fol. $137^{\mathrm{r}}$ ). Yet, he managed to escape with 'une femme de mauvaise vie' (Clairambault, 9 June 1719, o.c., fol. 149v).

116 Memorandum of the Council of Commerce, 31 January 1719, o.c.

117 Alimento, pp. 107-28 (p. 120); Doowhan Ahn, 'The Anglo-French Treaty of Commerce of 1713: Tory Trade Politicsm and the Question of Dutch Decline', History of European Ideas, 36 (2012), 167-80.

118 Treaty of Navigation and Commerce between Louis XIV and Queen Anne, Utrecht, 11 April 1713, CUD VIII/1, no. CLII, Art. XIX.

119 Clairambault, Livorno, 16 June 1719: AN, Marine, B1, 40, fol. $154^{\mathrm{r}}$.

120 Alimento, pp. 107-28 (p. 109).

121 Clairambault, Livorno, 21 July 1719: AN, Marine, B1, 40, fol. 180v".

122 Clairambault, Livorno: AN, Marine, B1, 40, fol. 135' : '[...] even if this would have been the case, trade in it would have been allowed under the Treaty of Utrecht, proscribing stopping vessels with no contraband aboard.'

123 AN, Marine, B1, 40, fol. 39. 


\section{THE DRAFT TREATY ${ }^{124}$}

In May 1719, the Council of the Marine drafted a convention aimed at the Republics of Genoa and Venice and the Grand Duchy of Tuscany. ${ }^{125}$ The inspiration came from an earlier proposal directed at the neutral Dutch Republic, drafted in November 1718, three months after the battle of Cape Passaro. ${ }^{126}$ Materially, the clauses pertained to domestic law. The treaty proposal amounted to a French imposition of legislation on the small neutral Italian states, but was of prime importance to safeguard Mediterranean trade. ${ }^{127}$ Its first article established free entrance to ports for any vessel, either warships or merchants, including those belonging to privateers, armed for war with commissions from their sovereign. However, the second article forbade the arming of vessels for war. Those who contravened these requirements had to be prevented from sailing by having their ships confiscated. Article three ordered all seizures by privateers to leave the relevant port within twenty-four hours and forbade their sale. A longer stay entailed the loss of the ship in question, the release of its crew, and the impossibility of the privateer's enforcing any further claim. This operation was similar to what had been agreed previously, during the War of the Spanish Succession, with the King of Denmark (who was neutral at the start of the war). ${ }^{128}$ The twenty-four

124 Convention project between Britain, France, Austria, the Grand Duchy of Tuscany and the Republics of Venice and Genoa, to maintain neutrality in the ports of their dominance and to avoid piracy, Paris, s.d., NA, SP, 78, 164, fols $82^{\mathrm{r}}-84^{\mathrm{v}}$. Williams, pp. 329-30.

125 Schnakenbourg, p. 23.

126 Stair to Craggs, Paris, 8 November 1718: NA, SP, 78, 162, fol. 293v; Frederik Dhondt, Balance of Power and Norm Hierarchy: Franco-British Diplomacy after the Peace of Utrecht (Leiden: Brill, 2015), p. 164.

127 Richard Whatmore, "Neither Masters nor Slaves': Small States and Empire in the Long Eighteenth Century', in Lineages of Empire: The Historical Roots of British Imperial Thought, ed. by Duncan Kelly (Oxford: Oxford University Press, 2009), pp. 53-81.

128 Schnakenbourg, p. 71. Art. 3, Treaty of Alliance between Denmark, Britain and the States-General, Odense, 20 January 1701, CUD VIII/1, no. I, 1. French diplomats tried to have the presence of French privateers accepted for Denmark and Norway. Frederick IV of Denmark allowed the sale of captures in his ports from 1711 on, in return for reciprocal permission for Danish subjects in Britain, the Republic and France. 
hour rule can be traced back to Jean-Baptiste Colbert's Marine Ordinance of 1681, forbidding privateers to stay longer in French ports, save when the seizure concerned an enemy ship. ${ }^{129}$

The problems encountered by French merchants were characterised as the exercise of 'criminal activities and piracy' by 'private persons, subject either to the allied Powers or the King of Spain', in order to enrich themselves in an unjust way, 'with avaricious intentions', without 'the permission to privateer on the basis of legitimate commissions issued by their sovereigns' (art. V.). Captains entering the ports of Genoa, Venice or the Grand Duchy of Tuscany would have had to submit themselves to compulsory verification by the local magistrates, as well as the consuls of the 'respective powers having an interest in the case'. In view of the incessant trouble described above, the text also aimed at the privateers as well as at the distribution of power between local jurisdictions and foreign consuls.

The Italian neutrals were equipped with their own jurisdictions, able to exercise judicial control over seizures. ${ }^{130}$ Their neutrality implied equal treatment for all belligerents. However, this concept was hard to sustain in view of the imbalance of power between the coalition and the King of Spain. ${ }^{131}$ Aubert, consul in Genoa, wrote an extensive memorandum on consular jurisdiction. He stated that Genoese maritime magistrates infringed upon French consular jurisdiction (governed by Colbert's 1681 ordinance), insofar as vessels or individuals from the French nation were concerned. Consular decisions were only enforceable after a Genoese notary declared them conformable to the laws and statutes of the Genoese Republic. That said, Aubert complained of excessive encroachments by the local judges, who treated cases on their merits. Another example is

129 Schnakenbourg, p. 7. See: Ordonnance de la Marine du mois d'Aoust 1681: Commentée \& Conférée sur les anciennes Ordonnances, le Droit Romain, \& les nouveaux Réglemens (Paris: Osmont, 1714), p. 336.

130 Request of 18 December 1718 by captain Gerfroid, merchant from St Tropez, to obtain the effective restitution of his effects seized by Venetian privateers in 1717 . AN, Marine, B1, 36, fol. $17^{\mathrm{r}}$.

131 E.g. de Silva, Livorno, 30 December 1718: AN, Marine, B1, fol. 21r. The Spanish consul had bought a vessel and raised the royal flag, loaded it with ammunition and sent it to the army in Sicily. As a reaction, the French consul Clairambault ordered French ships lying in the harbour to disembark after protestation of the Imperial consul. 
the decision of the Venetian Senate to systematically visit any foreign vessel, contrary to established Imperial and French privileges. Naturally, Charles VI's, Louis XV's and George I's consuls objected. ${ }^{132}$ Venice had to grant an exception to the Emperor, confirming his subjects' rights, and also allow French and British vessels to come and go without an official visit of inspection. ${ }^{133}$

Reports by French consuls on the peninsula alerted the Regent to the necessity of imposing clearer rules, even if this meant intrusion into domestic legislation. French consuls had jurisdiction over their own nationals, a privilege which they jealously guarded. For instance, the Regent issued an ordinance forbidding the Sossins merchant family to execute a local judicial decision obtained from municipal judges in Livorno against a certain Chavignon, another French merchant from Marseille. ${ }^{134}$ Disputes between French merchants, or any disputes whereby a French merchant acted as the defendant or debtor in a trial, were under the French consul's exclusive jurisdiction. Even several years of residence abroad could not change this reality. Appeals could only be heard before the (French) sovereign court of parliament closest to the foreign port, namely that of Provence:

On the basis of the law of nations, His Majesty has never conceived of nor tolerated any situation whereby disputes between his subjects would be dependent on other judges than those who give justice in his name, and under his authority. ${ }^{135}$

Beyond these parameters, merchants could only observe what transpired in proceedings before the domestic judges with responsibility for adjudicating seizures by Italian privateers: Aubert, consul in Genoa, had no choice but to respect a decision on a seized French vessel and to ignore the advice of the British consul to seize vessels armed in France and confiscated by Italian privateers. ${ }^{136}$ Attempts to reserve jurisdiction

132 Le Blond, Venice, 5 August 1719: AN, Marine, B1, 40, fols 191 1 -91v.

133 Le Blond, Venice, 12 August 1719: AN, Marine, B1, 40, fols $200^{\mathrm{v}}-01^{\mathrm{r}}$.

134 AN, Marine, B1, 40, fol. 62v .

135 Ibid., fol. 64다.

136 Answer by the Regent to consul Aubert in Genoa, 31 January 1719: AN, Marine, B1, 40, fol. 46r. 
over cases involving seized French vessels were unsuccessful. ${ }^{137}$ Moreover, Italian judges tended to uphold and maintain the neutral status of their port. This implied that they would refuse to arrest French, English or Imperial subjects participating in privateering for the King of Spain. ${ }^{138}$ As a result, treacherous or deserting subjects found a genuine safe haven to sell off the benefits of their depredations. Commerce with the enemy could thus continue under the Spanish flag. ${ }^{139}$ Spanish privateering vessels could in fact have been fitted out and armed in Marseille, raised the Spanish flag on the high seas, been staffed with French sailors, seized an English vessel and safely sailed to Genoa, where their prize could be sold with the help of French auctioneers. ${ }^{140} \mathrm{Or}$, on the other hand, the authorities of the Italian ports could insist on enforcing their neutral status, by threatening to visit and search all foreign vessels which docked in their harbours. ${ }^{141}$

A final clause of the draft treaty established sanctions in case a privateer should transpire to be acting on a false commission, under double commission (granted by two sovereigns), or, indeed, without any authorisation whatsoever. ${ }^{142}$ Vessel and merchandise alike were to be confiscated, to the advantage of the neutral state, which would punish captain, officers and crew as forbans and gens courans les mers sans aveu. ${ }^{143}$ However, these regulations did not come into force. Charles VI

137 E.g. de la Leurie, Naples, 14 August 1719: AN, Marine, B1, 40, fols 208 $-09^{\mathrm{v}}$.

138 Report by Aubert to the French Regent: AN, Marine, B1, 40, fol. 46.

139 E.g. Saint-Frémond, Venice, 20 May 1719: AN, Marine, B1, 40, fol. 135ㄴ-36r: a Spanish vessel sent from Sicily to the Spanish envoy in Venice was on the brink of returning, when the French consul ordered its conservatory seizure before a local court. The carriage would serve as an 'hypotheque' for the outstanding debts of its armator. With all material destined for Sicily locked inside the ship, the Spanish would never receive it.

140 Report by D’Auvergne, Genoa, 14 March 1719: AN, Marine, B1, 40, fol. $91^{v}$. Report by the widow David (Genoa), 4 March 1719: ibid., fol. 92 .

141 E.g. Report by St Frémond, Venice, 1 April 1719: AN, Marine, B1, 40, fol. 109v Combined Austrian, English and French pressure made this however very unlikely.

142 ' $[\ldots]$ no legal warfare, but disguised crime [...]', see: Bynkershoek, p. 107.

143 See: Joaquin Alcaide Fernandez, 'Hostes Humani Generis: Pirates, Slavers, and Other Criminals', in The Oxford Handbook of the History of International Law, ed. by Bardo Fassbender and Anne Peters (Oxford: Oxford University Press, 2012), pp. 120-44 (pp. 120-22). 
refused to adhere to the terms of this convention. ${ }^{144}$ As explained above, corsairs from Naples were among the most persistent threats to French commerce. If one of the three pillars of the alliance - namely the Emperor - would not take part, it was useless to attempt to impose the articles on Italian neutrals.

\section{EPILOGUE: THE ULTIMATE RECOURSE TO NATURAL LAW}

As French and British merchants alike voiced their anger at the commercial damage they had to suffer, the fundamental nature of free navigation between nations was at the heart of their argument. ${ }^{145}$ Falling back on the general law of nations as an avenue of complaint was not unique. During the conflict, France and Britain were frustrated with Dutch aloofness from the struggle for what they defined as being the common good of Europe. Hispano-Dutch trade continued unhampered during the War of the Quadruple Alliance, whereas France and Britain lost part of their market. In line with general Dutch attitudes to neutrality, the States-General preferred to be medius in bello, or non hostes. ${ }^{146}$ This meant that they preferred to gain in financial terms from the principles of free trade, rather than prioritising ruinous spending on their defence, as had been the case in the War of the Spanish Succession. ${ }^{147}$ This search for what one might describe as a temporary commercial advantage effectively removed the Dutch Republic from the 'top table' of European

144 Maricon to Courtes, Genoa, 11 July 1719: AN, Marine, B1, 40, fol. 161'

145 Chammorel, London, 28 September 1719: AN, Marine, B1, 40, fol. 237; ibid., 30 November 1719: AN, Marine, B1, 40, fol. 300'.

146 Bynkershoek, p. 60; Koen Stapelbroek, 'Dutch Decline as a European Phenomenon', History of European Ideas, 36 (2010), 139-52; Schnakenbourg, Entre la Guerre et la Paix; Jean-François Chanet and Christian Windler, Les Ressources des Faibles: Neutralités, Sauvegardes, Accommodements en Temps de Guerre (XVI'-XVIII Siècle) (Rennes: Presses Universitaires de Rennes, 2009); Jean Matthieu Mattei, Histoire du droit de la guerre, 1700-1819: Introduction à l'histoire du droit international: Avec une biographie des principaux auteurs de la doctrine internationaliste de l'antiquité à nos jours (Aix-en-Provence: Presses Universitaires d'Aix-Marseille, 2006), pp. 591-93.

147 Johan Aalbers, 'Holland's Financial Problems (1713-1733) and the Wars against Louis XIV', in Britain and the Netherlands, ed. by A.C. Duke and C.A. Tamse (The Hague: Martinus Nijhoff, 1977), pp. 79-123. 
negotiations during the conflict. Moreover, the freedom of commerce claimed by the Dutch in the War of the Quadruple Alliance contrasted with their own attitude three years later. In 1722, Emperor Charles VI granted an official patent to the Imperial East Indies Company in Ostend, one of the most important ports in the Austrian Netherlands. However, Britain and the Dutch Republic jointly moved to curb the potential success of their commercial competitor. The formal legal basis for the Company's elimination was the violation of the Treaty of Munster, at the occasion of which Philip IV of Spain had denied access to the parts of the Indies controlled by the Dutch to his 'Castilian' subjects.

The treaty of Munster's validity was connected to inherent limitations on the principle of free navigation on the high seas, as Hugo Grotius had expounded in his famous Mare Liberum. ${ }^{148}$ Most of the literature follows the Dutch thesis, supported by such influential names as Jean Barbeyrac, professor of public law in Groningen. Unfortunately, various pamphlets written against this commercial restrictiveness have been forgotten. ${ }^{149}$ However, one of these writings, attributed to the Imperial historiographer Jean du Mont de Carels-Kroon, ${ }^{150}$ who drafted the commercial treaty allowing the Ostend Company to trade directly in Spain, fundamentally undermined the Dutch point of view. ${ }^{151}$ What if the new King of Spain, Philip V, were to open his overseas dominions

148 Koen Stapelbroek, 'Trade, Chartered Companies, and Mercantile Associations', in The Oxford Handbook of the History of International Law, pp. 338-58; Robert Feenstra, 'Mare Liberum - Contexte Historique et Concepts Fondamentaux', in Grotius et l'Ordre Juridique International: Travaux du Colloque Hugo Grotius Genève, 10-11 Novembre 1983, ed. by Alfred Dufour, Peter Haggenmacher and Jiri Toman (Lausanne: Payot, 1985), pp. 37-42.

149 Michel Huisman, La Belgique Commerciale sous l'Empereur Charles VI: La Compagnie d'Ostende: Étude Historique de Politique Commerciale et Coloniale (Brussels: Lamertin, 1902).

150 Stephan Verosta, 'Droit International et Droit Interne chez Jean Dumont (1666-1727)', in Mélanges Offerts à Henri Rolin (Paris: Pedone, 1964), pp. 479-87.

151 Jean du Mont de Carels-Kroon, La vérité du fait, du droit, et de l'intérêt de tout ce qui concerne le commerce des Indes, etabli aux Pä̈s Bas Autrichiens par octroi de sa Majesté Impér. et Catholique ([n.p.]: [n. pub.], 1726). See more elaborately: Frederik Dhondt, 'Delenda est haec Carthago: The Ostend Company as a Problem of European Great Power Politics (1722-1727)', Revue Belge de Philologie et d'Histoirel Belgisch Tijdschrift voor Filologie en Geschiedenis, 93 (2015), 397-437. 
to Charles VI's subjects? Would not this new treaty lift the limitation installed in 1648 by his predecessor Philip IV? Just as in the case of Mediterranean trade, the inherent logic of geopolitical realities settled the affair. However, the flexibility of universal discourse on free trade as a natural right between sovereigns could not be eradicated. The Dutch Republic shifted from a militant position in the early seventeenth century, against the Hispano-Portuguese division of the world into two hemispheres at the Treaty of Tordesillas of 1494 and also against the British opinion of Mare Clausum, propagated by John Selden, ${ }^{152}$ to one of self-serving repression, and consolidation of its own position. ${ }^{153}$ Even if the Dutch abandoned this point of view in order to eliminate a competitor, the validity of Grotius' initial affirmation remained. The Dutch scholar had referred to the freedom to trade and navigate, as enlarged upon in Justinian's Digest. In view of the lack of broader ratification of the Franco-British trade treaty, this would remain the bedrock of merchants' legal defence, at any time when their vessels had been 'arrested against the law of nations and contrary to the treaties concluded between France and England'. ${ }^{154}$

\section{BIBLIOGRAPHY}

Archival Sources

Paris, Archives Nationales

Marine, B1

\section{Printed Primary Sources}

Bynkershoek, Cornelius van, Quaestionum iuris publici libri duo, trans. by Tenney Franck (Washington: Carnegie Institute, 1930 [1737])

152 Mónica Brito Vieira, 'Mare Liberum vs. Mare Clausum: Grotius, Freitas, and Selden's Debate on Dominion over the Seas', Journal of the History of Ideas, 64 (2003), 361-77.

153 Martti Koskenniemi, 'International Law and the Emergence of Mercantile Capitalism: Grotius to Smith', in The Roots of International Law/Les Fondements du Droit International: Liber Amicorum Peter Haggenmacher, ed. by Pierre-Marie Dupuy and Vincent Chetail (Leiden: Brill, 2013), pp. 3-37 (p. 22).

154 Clairambault (Livorno), 2 June 1719, AN, Marine, B1, 40, fol. 143v. 
Child, Josiah, Discourse of Trade, Wherein is Recommended Several weighty Points relating to Companies of Merchants, the Act of Navigation, Naturalization of Strangers, and our Woollen Manufactures, the Balance of Trade And the Nature of Plantations, and their Consequences, in Relation to the Kingdom, are Seriously Discusses (London: Sowle, 1718)

Considérations sur la guerre d'Italie ([n.p.]: [n. pub.], [1718])

Galluzzi, Riguccio, Histoire du grand duché de Toscane, sous le gouvernement des Médicis, traduite de l'italien, 3 vols (Paris: Hôtel Serpente, 1782-1784)

Massuet, Pierre, Histoire de la guerre présente contenant tout ce qui sest passé de plus important en Italie, sur le Rhin, en Pologne \& dans la plupart des Cours de l'Europe (Amsterdam: Brunel \& Wetstein, 1735)

Mercure historique et politique, Contenant l'état présent de l'Europe, ce qui se passe dans toutes les Cours, l'Intérêt des Princes, leurs Brigues, \&o généralement tout ce quill y a de curieux pour le Mois de Janvier 1719 (La Haye: Les Frères Van Dole, 1719)

Mont de Carels-Kroon, Jean du, La vérité du fait, du droit, et de l'intérêt de tout ce qui concerne le commerce des Indes, etabli aux Païs Bas Autrichiens par octroi de sa Majesté Impér. et Catholique ([n.p.]: [n. pub.], 1726)

—- ed., Corps Universel Diplomatique du Droit des Gens (CUD), 8 vols (The Hague: Adrien Moetjens, 1726-1731)

Ordonnance de la Marine du mois d'Aoust 1681: Commentée \& Conférée sur les anciennes Ordonnances, le Droit Romain, \& les nouveaux Réglemens (Paris: Osmont), 1714

Tosini, Pietro, La liberté de l'Italie demontrée à ses princes et à ses peuples, traduite de l'italien (Amsterdam: Steenhouwer \& Uytwerf, 1718)

Vayrac, Jean de, État présent de l'Espagne, où l'on voit une géographie historique du Pays (Amsterdam: Steenhouwer \& Uytwerp, 1719)

\section{Secondary Works}

Aalbers, Johan, 'Holland's Financial Problems (1713-1733) and the wars against Louis XIV', in Britain and the Netherlands, ed. by A.C. Duke and C.A. Tamse (The Hague: Martinus Nijhoff, 1977), pp. 79-112

Ahn, Doowhan, 'The Anglo-French Treaty of Commerce of 1713: Tory Trade Politicsm and the Question of Dutch Decline', History of European Ideas, 36 (2012), 167-80

Alcaide Fernandez, Joaquin, 'Hostes Humani Generis: Pirates, Slavers, and other Criminals', in The Oxford Handbook of the History of International Law, ed. by Bardo Fassbender and Anne Peters (Oxford: Oxford University Press, 2012), pp. $120-44$

Alimento, Antonella, 'Commercial Treaties and the Harmonisation of National Interests: The Anglo-French Case (1667-1713)', in War, Trade and Neutrality: Europe and the Mediterranean in the Seventeenth and Eighteenth Centuries, ed. by Antonella Alimento (Milan: FrancoAngeli, 2011), pp. 107-28

Anderson, Gary M. and Adam Gifford jr., 'Privateering and the Private Production of Naval power', Cato Journal, 11 (1991-1992), 99-122 
Bély, Lucien, Espions et Ambassadeurs au Temps de Louis XIV (Paris: Fayard, 1990) — , ed., La Présence des Bourbons en Europe, XVIe-XXIe Siècle (Paris: Presses Universitaires de France, 2003)

Bérenger, Jean, 'Le Conflit entre les Habsbourg et les Bourbons (1598-1792)', Revue d'Histoire Diplomatique, 116 (2002), 192-232

Bourgeoise, Émile, La Diplomatie Secrète au XVIIIe Siècle, Ses Débuts, 3 vols (Paris: Armand Colin, 1909-1910)

Brito Vieira, Mónica, 'Mare Liberum vs. Mare Clausum: Grotius, Freitas, and Selden's Debate on Dominion over the Seas', Journal of the History of Ideas, 64 (2003), 361-77

Bromley, John S., Corsairs and Navies 1660-1770 (London: Hambledon Press, 1987)

Browning, Reed, The War of the Austrian Succession (New York: St Martin's Griffin, 1995)

Campbell, Peter R., Power and Politics in Old Regime France, 1720-1745 (London: Routledge, 1996)

Caridi, Giuseppe, Carlo III: Un grande Re Riformatore a Napoli e in Spagna (Rome: Salerno, 2014).

Castagnoli, Paolo, Il Cardinale Giulio Alberoni, 3 vols (Piacenza: Collegio Alberoni, 1929)

Chanet, Jean-François and Christian Windler, eds., Les Ressources des Faibles: Neutralités, Sauvegardes, Accommodements en Temps de Guerre (XVIe-XVIIIe Siècle) (Rennes: Presses Universitaires de Rennes, 2009)

Chaussinand-Nogaret, Guy, Le Cardinal Dubois, 1656-1723 ou une Certaine Idée de l'Europe (Paris: Perrin, 2000)

Corvisier, André, 'Présence de la Guerre au XVIIe Siècle', in Guerre et Paix dans l'Europe du XVIIe Siècle, ed. by Lucien Bély, Jean Bérenger and André Corvisier, 2 vols (Paris: S.E.D.E.S., 1991), I, pp. 13-27

Crouzet, François, 'La Rivalité Commerciale Franco-Anglaise dans l'Empire Espagnol, 1713-1789', Histoire, Économie et Société, 31 (2012), 19-29

Condamine, Pierre de la, Pontcallec: Une Etrange Conspiration au Cour de la Bretagne ([Mayenne]: Y. Floc'h, 1988).

Davis, Ralph, 'English Foreign Trade 1700-1774', Economic History Review, 15 (1962), 285-303

Dhondt, Frederik, 'From Contract to Treaty: The Legal Transformation of the Spanish Succession, 1659-1713', Journal of the History of International Law - Revue d'Histoire du Droit International, 13 (2011), 347-75

, 'Kardinaal Dubois door Hyacinthe Rigaud (1723): Een Insider's View op een Bibliotheek van de Macht in de Grand Siècle', Pro Memorie: Bijdragen tot de Rechtsgeschiedenis der Nederlanden, 16 (2014), 45-54

- Balance of Power and Norm Hierarchy: Franco-British Diplomacy after the Peace of Utrecht (Leiden: Brill, 2015)

-, 'Delenda est haec Carthago: The Ostend Company as a Problem of European Great Power Politics (1722-1727)', Revue Belge de Philologie et d'Histoire/Belgisch Tijdschrift voor Filologie en Geschiedenis, 93 (2015), 397-437 
Duchhardt, Heinz and Martin Espenhorst, eds., Utrecht-Rastatt-Baden 1712-1714: Ein europäisches Friedenswerk am Ende des Zeitalters Ludwigs. XIV (Göttingen: Vandenhoeck \& Ruprecht, 2013)

Dupilet, Alexandre, La Régence Absolue: Philippe d'Orléans et la Polysynodie (Seyssel: Champ Vallon, 2011)

— Le Cardinal Dubois: Le Génie Politique de la Régence (Paris: Tallandier, 2015)

Fausta Gallo, Francesca, 'Una difficile Fedeltà: L'Italia durante la Guerra di Successione Spagnola', Cheiron, 39-40 (2004), 245-66

Feenstra, Robert, 'Mare Liberum - Contexte Historique et Concepts Fondamentaux', in Grotius et l'Ordre Juridique International: Travaux du Colloque Hugo Grotius Genève, 10-11 Novembre 1983, ed. by Alfred Dufour, Peter Haggenmacher and Jiri Toman (Lausanne: Payot, 1985), pp. 37-42

Frey, Marsha and Linda Frey, eds., The Treaties of the War of the Spanish Succession: An Historical and Critical Dictionary (Westport: Greenwood, 1995)

Gaurier, Dominique, Histoire du Droit International (Rennes: Presses Universitaires de Rennes, 2014)

Graham, Aaron, Corruption, Party, and Government in Britain, 1702-1713 (Oxford: Oxford University Press, 2015)

Grüne, Niels and Simona Slanička, eds., Korruption. Historische Annäherungen an eine Grundfigur politischer Kommunikation (Göttingen: Vandenhoeck \& Ruprecht, 2010)

Harcourt-Smith, Simon, Cardinal of Spain: The Life and Strange Career of Giulio Alberoni (New York: Knopf, 1955)

Huisman, Michel, La Belgique Commerciale sous l'Empereur Charles VI: La Compagnie d'Ostende: Étude Historique de Politique Commerciale et Coloniale (Bruxelles: Lamertin, 1902)

Kaiser, Wolfgang and Guillaume Calafat, 'Violence, Protection and Commerce: Corsairing and Ars Piratica in the Early Modern Mediterranean', in Persistent Piracy: Maritime Violence and State Formation in Global Historical Perspective, ed. by Stefan Amirell and Leos Müller (London: Palgrave, 2014), pp. 69-92.

Kolb, Robert, 'The Protection of the Individual in Times of War and Peace', in The Oxford Handbook of the History of International Law, ed. by Bardo Fassbender and Anne Peters (Oxford: Oxford University Press, 2012), pp. 317-37

Koskenniemi, Martti, 'International Law and the Emergence of Mercantile Capitalism: Grotius to Smith', in The Roots of International Law/Les Fondements du Droit International: Liber Amicorum Peter Haggenmacher, ed. by Pierre-Marie Dupuy and Vincent Chetail (Leiden: Brill, 2013), pp. 3-37

León Sanz, Virginia, Carlos VI: El Emperador que no pudo ser Rey de España (Madrid: Aguilar, 2003)

Mattei, Jean Matthieu, Histoire du droit de la guerre, 1700-1819: Introduction à l'histoire du droit international: Avec une biographie des principaux auteurs de la doctrine internationaliste de l'antiquité à nos jours (Aix-en-Provence: Presses Universitaires d'Aix-Marseille, 2006)

McJimsey, Robert R., 'Shaping the Revolution in Foreign Policy: Parliament and the Press, 1689-1730', Parliamentary History, 25 (2006), 17-31 
McLachlan, Jean O., Trade and Peace with Old Spain 1667-1750 (Cambridge: Cambridge University Press, 1940)

McKay, Derek, 'Bolingbroke, Oxford and the Defence of the Utrecht Settlement in Southern Europe', English Historical Review, 86 (1971), 264-84

Meyer, Jean, 'Marine de guerre', in Dictionnaire de l'Ancien Régime, ed. by Lucien Bély (Paris: Presses Universitaires de France, 2006), pp. 802-04

Mongiano, Elisa, 'Universae Europae Securitas': I Trattati di Cession della Sardegna a Vittorio Amedeo II di Savoia (Turin: Giappichelli Editore, 1995).

Ozanam, Denise and Didier Ozanam, Les Diplomates Espagnols au XVIIIe Siècle (Madrid/Bordeaux: Casa de Velázquez/Maison des Pays Ibériques, 1998)

Pesendorfer, Franz, Österreich--Grossmacht im Mittelmeer?: Das Königreich Neapel-Sizilien unter Kaiser Karl VI (1707/20-1734/35) (Vienna: Böhlau Verlag, 1998)

Phillimore, Robert, ed., Commentaries upon International Law, 2 vols (London: Butterworth, 1879-1889)

Quazza, Guido, Il Problema Italiano e l'Equilibrio Europeo, 1720-1738 (Turin: Deputazione Subalpina di Storia Patria, 1965)

Reese, Armin, Europäische Hegemonie und France d'outre-mer: Koloniale Fragen in der französischen Aussenpolitik 1700-1763 (Stuttgart: Steiner, 1988)

Salerno, Emanuele, 'Stare Pactis and Neutrality: Grotius and Pufendorf in the Political Thought of the Early Eighteenth Century Grand Duchy of Tuscany', in War, Trade and Neutrality: Europe and the Mediterranean in the Seventeenth and Eighteenth Centuries, ed. by Antonella Alimento (Milan: FrancoAngeli, 2011), pp. $188-202$

Schnakenbourg, Eric, Entre la Guerre et la Paix: Neutralité et Relations Internationales, XVIIe-XVIIIe Siècles (Rennes: Presses Universitaires de Rennes, 2013)

Spagnoletti, Angelantonio, 'Il Dibattito Politico a Napoli sulla Successione di Spagna', Cheiron, 39-40 (2004), 267-310

Stapelbroek, Koen, 'Dutch Decline as a European Phenomenon', History of European Ideas, 36 (2010), 139-52

— , 'Trade, Chartered Companies, and Mercantile Associations', in The Oxford Handbook of the History of International Law, ed. By Bardo Fassbender and Anne Peters (Oxford: Oxford University Press, 2012), pp. 338-58

_- 'Between Utrecht and the War of the Austrian Succession: The Dutch Translation of the British Merchant of 1728', History of European Ideas, 40 (2014), $1026-43$

Stapells Johnson, Victoria, Corsairs of Santo Domingo: A Socio-Economic Study, 1718-1779 (unpublished master thesis, University of Ottawa, 1985).

Steiger, Heinhard, 'Rechtliche Strukturen der europäischen Staatenordnung 16481792', Zeitschrift für ausländisches öffentliches Recht und Völkerrecht, 59 (1999), $609-49$

Storrs, Christopher War, diplomacy and the Rise of Savoy, 1690-1720 (Cambridge: Cambridge University Press, 1999)

_ - 'The Spanish Risorgimento in the Western Mediterranean and Italy 17071748', European History Quarterly, 62 (2012), 555-77 
Stücheli, Rolf, Der Friede von Baden (Schweiz) 1714 (Freiburg: Universitätsverlag, 1997)

Sutton, John L., The King's Honour and the King's Cardinal: The War of the Polish Succession (Lexington: Kentucky, 1980)

Verosta, Stephan, 'Droit International et Droit Interne chez Jean Dumont (16661727)', in Mélanges Offerts à Henri Rolin (Paris: Pedone, 1964), pp. 479-87

Vesnitch, Mil. R., 'Cardinal Alberoni: An Italian Precursor of Pacifism and International Arbitration', The American Journal of International Law, 8 (1913), 51-82

Vincens, Émile, Histoire de la République de Gènes, 3 vols (Paris: F. Didot, 1842)

Waquet, Jean-Claude, Le grand-duché de Toscane sous les derniers Médicis: Essai sur le système des finances et la stabilité des institutions dans les anciens Etats italiens (Romel Paris: Ecole Française de Rome/de Boccard, 1990)

Whatmore, Richard, "Neither Masters nor Slaves': Small States and Empire in the Long Eighteenth Century', in Lineages of Empire: The Historical Roots of British Imperial Thought, ed. by Duncan Kelly (Oxford: Oxford University Press, 2009), pp. 53-81

Williams, Basil, Stanhope: A Study in Eighteenth-Century War and Diplomacy (Oxford: Clarendon Press, 1932)

Woodfine, Philip, Britannia's Glories: The Walpole Ministry and the 1739 War with Spain (Woodbridge: Royal Historical Society, 1998)

Frederik Dhondt - Assistant Professor at the Free University of Brussels (VUB), Guest Professor at the University of Antwerp and Postdoctoral Fellow of the Research Foundation Flanders (FWO/UGent); e-mail: Frederik.Dhondt@vub.ac.be 